\title{
The Implementation Project Based Learning Model Assisted with Visual Media in Mathematics Learning
}

\author{
Sulvianti \\ Department of Mathematics Education \\ Muhammadiyah University of Parepare \\ Parepare, Indonesia \\ soelvianthie@gmail.com
}

\begin{abstract}
The research is based on the importance of Mathematics to master the advance growth of Science and Technology. Therefore, students need to be taught Mathematics which is not just read or memorize its formulas. It will be meaningful if it learnt contextually by involving more students to explore and build self-competencies in order to maintain various potentions and truth scientifically. In relation to this, researcher considered to strengthen the scientific approach, integrated thematic learning, and discovery/inquiry learning. Learning model is one of prominent factor in achieving the learning objectives. Project-based Learning is one of relevant model to be implemented contextually in learning whether it individually or in groups. It gives the teachers opportunity to maintain the learning by providing students their chance to make a proper project based on their competencies. The results of the project are temporarily products such as written and oral report, presentation or recommendation This project-based learning model is also enriched with visual media to create students' better understanding towards the materials. It also encourage them and give clear reflection of mathematics learning in reality.
\end{abstract}

\section{Keywords-Project-based Learning, Visual Media}

\section{INTRODUCTION}

Mathematics as one of fundamental knowledge holds important role in mastering the science and technology. It is a logical instrument in shaping the students' attitudes toward crativity, logical and systematical thinking ability. Considering the importance of mathematics in rapid science and technology, it is necessary to teach students about mathematics in regarding that they are also expected to be both subject and object of the qualified mathematics education.

Mathematics is not enough if it only be learnt through reading, imagining, and memorizing. It will be more meaningful if it learnt contextually by involving more students to explore and develop self-competencies through potentions and truth development scientifically. Therefore, the teacher holds inportant role as well as the students themselves in determining the effectiveness of the teaching and learning process. However, there is a problem occured that students are barely hard to receive the materials and it makes them dependent to their teacher in solving their problem efficiently. It also makes them memorize the formulas only without understanding the meaning and cannot apply it in any applicable situation.

To overcome this, it is necessary to strengthen the scientific (thematic), thematic (integrated thematic) approach, and thematic (in a subject) the need to apply discovery / inquiry learning. One of the learning models that is relevant to contextual implementation both individual and group, and is expected to overcome the problems in learning mathematics is a project based learning model (Project Based Learning).

The project based learning model in this study is accompanied by the use of visual media, in the hope that visual elements enable the creation of learning messages through visualization forms, so as to help provide student learning motivation and provide an overview of the application of mathematics in the real world so that learning will become more meaningful.

On the basis of the above thought, the researcher wants to apply a model of learning, which is a project-based learning model along with visual media in learning mathematics.

\section{LITERATURE REVIEW}

\section{A. Project-based Learning Model}

In Australia the project-based learning model is called the rich task. At Ninestiles School Birmingham, England is called a reality-base learnig. At Kent Homewood School UK, this learning is called total learning. By Bellanca [1], this project-based learning is called enriched learning.

The term project is taken from manual arts (handwork), where the student must complete a certain job. The main thing in project-based learning is "the active purpose of the learner". Students themselves must accept the project and implement it. If the student is making a bridge on the teacher's instructions, it is not a project. Conversely, if students read books driven by the desire to seek or understand something, it includes the project.

Project-based learning is one of the models used in learning to engage and utilize the experience of everyday life as a learning material. The privilege of this learning is that students are given the freedom of thinking of individuals or groups to achieve goals.

[2] states that "project-based learning or learningbased learning as a learning model involving learners in knowledge transfer". Project-based learning model resembles problem-based learning this is because the beginning of learning based on the problems revealed, as well as collaborative learning activities or groups that emphasize the environment of learners to be active. The difference lies in the object, where the problem-based learning is required the formulation of the problem, data collection and analysis while in project-based learning, learners are more encouraged in 
project-based learning, learners are more encouraged in designing or designing activities from start: formulate jobs, calculate, carry out the work and evaluate the results.

Based on the above opinion, it can be concluded that Project Based Learning is one of the learning method that emphasizes the activity of students both individually and in groups, and able to develop students' creativity in developing their thinking.

Characteristics of project-based learning, Learners make decisions and create frameworks:

1. There is a problem that the solution has not been determined before

2. Learners design the process to achieve results

3. Learners are responsible for obtaining and managing the information collected

4. There is continuous evaluation

5. Learners regularly look back at what they are doing

6. The final product result and evaluated its quality

The project-based learning design was developed based on three main pillars, including; contextual, collaborative, and autonomous learners. Based on these three pillars, project-based learning procedures are designed in 6 stages as follows:

1. Facing students on real issues in the field, and encouraging them to identify the real problem (searching).

2. Students are asked to find alternative and formulation of solving strategy.

3. Students are guided to do the planning (designing)

4. Guided students produce learning media that has been designed in the previous stage (producing / creating).

5. Students are guided to conduct product testing (evaluating)

6. Students are asked for presentation between groups (sharing)

Linkage of Project Method Learning to Mathematics Learning

Activity is very important in improving students' mathematics learning outcomes, because in the learning process without the existence of a student activity, the learning will not achieve maximum results.

Students who are active in learning will get good learning outcomes compared to students who are passive in learning. Thus the activity is needed in learning activities, because everything will not be achieved maximally if every individual is not active in carrying out an activity.

Through this project-based learning students will be active in the process of learning mathematics, by developing the ability and creativity so that the responsibility is entirely on the students so that the process of learning mathematics goes as expected.

\section{B. Visual Media}

Learning process is a communication process. In a communication process always involves three main components, namely the component of the message sender (teacher), the component of the message recipient (student), and the component of the message itself which is usually a subject matter. Sometimes in the learning process communication failure occurs. To avoid all that, the teacher can develop learning strategies by utilizing various media and learning resources [2].

The word media comes from the Latin medius which literally means middle, intermediate, or introduction. In advance, more specifically, the sense of the media in the learning process is defined as graphic, photographic, or electronic tools for capturing, processing and rearranging visual or verbal information. Media can also be interpreted as anything that can be used to channel the message, stimulate the mind, feelings, attention, and willingness of students, so that can be encouraged to be involved in the learning process. [3].

In general, media is a plural word of medium, which means intermediary or introduction. The word media applies to various activities or endeavors, such as media in conveying messages, magnetic delivery media or heat in engineering. The term media is also used in the field of teaching or education so that the term becomes a medium of education or learning media.

[2] argues that, visual media is a media that can only be seen alone, does not contain elements of sound. Included in the visual media are slide shows, photographs, transparencies, paintings, drawings, and various forms of printed materials such as graphics media and so on. Hernawan (2007) visual media is a media that can only be seen. Next Asyhar (2011) visual media is a medium in which there are elements consisting of lines, shapes and textures. Ashar (2011) visual media is the type of media used only rely on the senses of vision such as print media such as books, journals, image maps, and so forth.

The use of learning media by teachers in the learning process must be in accordance with student learning needs so that it can be used appropriately to support the achievement of learning objectives. Hernawan (2007: 39) revealed that there are three main things that need to be considered in the selection of instructional media, namely (a) the purpose of media selection, (b) media characteristics, and (c) alternative learning media that can be selected. Meanwhile, Arsyad (2011: 75-76) reveals there are several criteria that need to be considered in choosing the media, that is (a) in accordance with the objectives to be achieved, (b) appropriate to support the content of the facts, (c) practical, flexible, and long-lasting, (d) skilled teachers use them, (e) target groupings, and (f) technical quality.

Based on the above explanation it can be concluded that before using the media in the learning process should pay attention to several things, namely (a) the purpose of media selection, (b) media characteristics, (c) practicality, flexibility and media resilience, (d) using the media, (e) target grouping, and (f) technical quality. The process of using learning media will be more efficient if teachers pay attention to the first learning media that will be used before using in the learning process.

\section{Research Hypotheses}

Based on the above framework, the hypothesis of this research action is: "the activity and student learning achievement can 
be increased if the project-based learning is applied along with visual media in learning".

\section{RESEARCH METHOD}

\section{A. Research Design}

This research is a classroom action research that is descriptive and aims to reveal the results of research according to data obtained in the field. In this case to obtain information, if applied project-based learning with visual media, then the activity and learning outcomes of XI IPA1 students in MA DDI Tellu Limpoe can be increased.

\section{B. Factors Examined}

Factors examined in this research are:

1. Student factors, by viewing student activities in the learning process by applying project-based learning with visual media.

2. Teacher factor, by seeing how the teacher implements project-based learning method along with visual media in learning.

3. Factors of learning outcomes, by looking at test results obtained by students at the end of the cycle to determine the success rate of students through the implementation of project-based learning model with visual media.

A. Research Variables and their Operational Definitions

1. The result of mathematics learning in this research is the ability obtained by the students after attending the mathematics lesson which is measured by using the result of learning test which is the result of the score.

2. While project-based learning is referred to in this study is a learning activity by providing tasks or projects to students, in the form of math problems where the results obtained accounted for.

3. The results of learning mathematics is said to increase if there is an increase from cycle I to the next cycle.

\section{Research Procedure}

This research is conducted in two cycles, where the cycle is each stage consists of planning, implementation, observation and reflection. The data collection in this research was done two ways, namely: (1) learning achievement data obtained by giving test to students at each end of cycle, (2) data about learning situation obtained through observation result by using observation sheet.

\section{Research Instrument}

To obtain accurate data in this research, the researcher use instrument instrument. Instrument used consists of:

1. Student observation sheet

This observation sheet is used to observe student activities such as attendance, attention, seriousness, and student activeness in the learning process.

2. Teacher observation sheet

Teacher observation sheets are used to observe activities, in this case is the ability of teachers to manage learning.

3. Test the learning outcomes
The test of learning outcomes is used to measure the success rate of students on mathematics subject matter.

\section{E. Procedure of Collecting Data}

1. Data Source

Sources of data on this class action research is the students of MA DDI Tellu Limpoe Sidrap class XI IPA1 even semester.

\section{Data Types}

The type of data obtained from the data source is the result of student learning and activity during the learning process.

3. How to Get Data

The way of collecting data in this study are as follows: techniques.

a. Data on learning outcomes is obtained by using test

b. Data about student activity in learning is obtained by using observation

technique

\section{F. Technique of Data Analysis}

The collected data is then analyzed by qualitative and quantitative analysis. For students' mathematics learning outcomes, standard categorization techniques adopted by the Ministry of Education and Culture [4]are as follows: (1) The score of $85 \%-100 \%$ is categorized as very high; (2) Scores of $65 \%-84 \%$ are categorized as high; (3) Scores of 55\% - 64\% are categorized as being; (4) The score of $35 \%-54 \%$ is categorized as low; (5) $0 \%-34 \%$ are categorized as very low.

The indicators of success of this study are: (1) Increasing the average score of student learning outcomes from cycle I to the next cycle; (2) Increasing the percentage of students' learning mastery from cycle I to the next cycle. The completeness of individual students' learning is said to be complete if students achieve $65 \%$ of KKM standards and complete in classical if $85 \%$ of students who complete learning; (3) Increased student activity in learning process in every cycle.

\section{FINDINGS AND DISCUSSION}

\section{A. Research Findings}

This section discusses the results of research that attention to improving student learning outcomes through project-based learning model with visual media. At the end of cycle I tested the results of learning mathematics in the form of description / essay after the presentation of the finished material. Description of result of cycle I test can be seen in Table 1 below.

TABle 1. Statistical Result of Students' MATH SCORE IN CyCle I

\begin{tabular}{|l|l|}
\hline Statistic & Statistical Score \\
\hline Subjects & 20 \\
Higher score & 85 \\
Lower score & 40 \\
Range & 45 \\
Mean score & 66,70 \\
Standard of deviation & 12,67 \\
Median & 69,44 \\
\hline
\end{tabular}


Based on Table 1 it can be seen that the average score of students' math learning abilities after the action is taken in cycle I by using project-based learning along with visual media that is equal to 66.70 from ideal score 100 . The lowest score achieved is 40, and the highest score is 85 .

If the results of learning mathematics are grouped into five categories, then the obtained frequency distribution and percentage of students' mathematics learning outcomes in table 2 below:

Table 2. Frequency Distribution and Percentage of Student MATHEMATICS LEARNING OUTCOMES IN CYCLE I

\begin{tabular}{cllll}
\hline $\begin{array}{c}\text { Level of } \\
\text { Mastery }\end{array}$ & Score & Category & Frequency & Percentage \\
\hline $85 \%-$ & $85-$ & Very high & 1 & 5,0 \\
$100 \%$ & 100 & High & 14 & 70,0 \\
$65 \%-$ & $65-$ & Medium & 1 & 5,0 \\
$84 \%$ & 84 & Low & 4 & 20,0 \\
$55 \%-$ & $55-$ & Very low & 0 & 0 \\
$64 \%$ & 64 & & & \\
$35 \%-$ & $35-$ & & & \\
$54 \%$ & 54 & & & \\
$0 \%$ & $-0-34$ & & & 100 \\
$34 \%$ & & & 20 & \\
\hline Total & & & \\
\hline
\end{tabular}

Table 2 shows that the students who are categorized as very high learning outcomes are 1 person (5.0\%), high 14 people $(70.0 \%)$, while 1 person $(5.0 \%)$ and 4 persons $(20.0 \%)$ in the low or very low category. So it can be argued that the average score of mathematics learning outcomes after students held project-based learning with visual media in cycle I are in high category. This means that the average increase in students' learning ability of class XI IPA1 MA DDI Tellu Limpoe class XI IPA1 after project-based learning along with visual media are in high category.

If the students' mathematics learning result in cycle I is analyzed with the percentage of students' mathematics learning completeness, it can be seen in Table 3 below.

Table 3. Frequency Distribution of Students' Mathematics COMPLETENESS IN CYCLE I

\begin{tabular}{lllll}
\hline Score & $\begin{array}{l}\text { Interval } \\
\text { score }\end{array}$ & Category & Frequency & Percentage \\
\hline $65-$ & $65-100$ & Complete & 15 & 75,0 \\
100 & & & & \\
$0-64$ & $0-64$ & Incomplete & 5 & 25,0 \\
\hline Total & & & & 100 \\
\hline
\end{tabular}

Table 3 above shows the percentage of classical completeness in cycle I that is equal to $75 \%$ (15 of 20) students are in the category of completion and $25 \%$ (5 of 20) students are in the category is not complete, this means there are 5 students who need improvement they have not yet reached a classical completeness.

The data analyzed qualitatively is the result of observation on student activity in learning by using projectbased learning model along with visual media. The activities of students who will be observed in cycle I and next, as follows: (1) Students who attend during the learning process; (2) Students who pay attention to teacher explanation; (3) Students who ask questions to teachers; (4) Students working with their groups; (5) Students holding group discussions; (6) Students who solve project questions in the form of LKS to each group; (7) Students who do homework.

Percentage of student activity in cycle I can be seen in diagram 4.1, below.

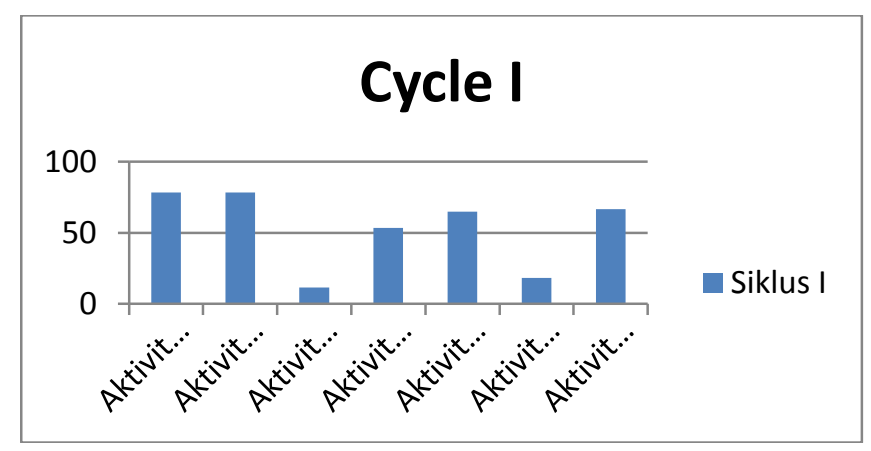

Fig.1. cycle 1

Based on the results of observation of student activity as a whole during the learning activity is quite enough because there are only some criteria that have not been fulfilled. Students' understanding of the material and the participation of students in the classroom is lacking because, there are still students who do not want to give opinions to solve the problem.

The researcher and the teacher discussed the results of the action based on the results of the observations and the results of the first cycle test to determine the improvement in the next cycle.

1. Here are the things that have been achieved in cycle I: Students are interested to follow the activities in each learning.

2. Teachers always help students in solving problems that occur.

3. Students begin to dare to ask if there are things they have not understood.

But there are some shortcomings and weaknesses in the learning process in cycle I so it needs to be improved in cycle II.

At the end of cycle II, the result of learning test in the form of essay essay description after the presentation of the finished material, the quantitative description of the students' mathematics learning outcomes based on the test results in cycle II can be seen in Table 6 below. 
TABle 4 Statistical Result of Students’ Math Score IN CyCle II

\begin{tabular}{ll}
\hline Statistic & Statistical Score \\
\hline Subjects & 20 \\
Highest score & 95 \\
Lower score & 55 \\
Range & 40 \\
Mean score & 78,00 \\
Standard of deviation & 10,05 \\
Median & 79,28 \\
\hline
\end{tabular}

Based on tabel 4. can be seen that the average score of students' math learning ability after the action is taken in cycle II by using project-based learning model along with visual media that is equal to 78.00 from ideal score 100. The lowest score achieved is 55, and the highest score is 95 .

If the results of learning mathematics are grouped into five categories, then obtained as in table 6 below:

Table 5. Frequency Distribution and Percentage of Student MATHEMATICS LEARNING OUTCOMES IN CYCLE II

\begin{tabular}{lllll}
\hline $\begin{array}{l}\text { Level of } \\
\text { Mastery }\end{array}$ & Score & Category & Frequency & Percentage \\
\hline $85 \%-100 \%$ & $85-100$ & Very high & 9 & 45,0 \\
$65 \%-84 \%$ & $65-84$ & High & 9 & 45,0 \\
$55 \%-64 \%$ & $55-64$ & Medium & 2 & 10,0 \\
$35 \%-54 \%$ & $35-54$ & Low & 0 & 0 \\
$0 \%-34 \%$ & $0-34$ & Very low & 0 & 0 \\
\hline Total & & & 20 & 100 \\
\hline
\end{tabular}

Based on Table 5 shows that the percentage of students' learning ability scores after applied project-based learning along with visual media, from 20 students, obtained 0 students or $0 \%$ are in very low category, 0 students or $0 \%$ are in low category, 2 students or $10 \%$ are in the medium category, 9 students or $45 \%$ are in high category, and 9 students or $45 \%$ are in very high category.

Based on the results of data analysis in Table 6 shows the average score of students' learning ability in cycle II is 78.0. If the average score of the students is included in Table 6 then the average score of students is in the high category. This means that the average increase in students' learning ability of class XI IPA1 MA DDI Tellu Limpoe after project-based learning along with visual media is in the high category.

If the mathematics learning result of students in cycle II is analyzed with the percentage of students' mathematics learning mastery, then it can be seen in Table 6 below.
Table 6 Frequency Distribution of Students' Mathematics COMPLETENESS IN CYCLE II

\begin{tabular}{lllll}
\hline Score & $\begin{array}{l}\text { Interval } \\
\text { score }\end{array}$ & Category & Frequency & Percentage \\
\hline $65-$ & $65-100$ & Complete & 18 & 90,0 \\
100 & & & & \\
\hline $0-64$ & $0-64$ & Incomplete & 2 & 10,0 \\
\hline Total & & & 20 & 100 \\
\hline
\end{tabular}

Based on the above table shows the percentage of classical completeness of $90 \%$, which included in the category of complete 18 students and 2 students included in the category is not complete. Overall, the data shows the achievement of the classical which exceeds from the achievement of $85 \%$ indicator.

If the result test of cycle I and cycle II is included in diagram 4.2, it will appear as follows.

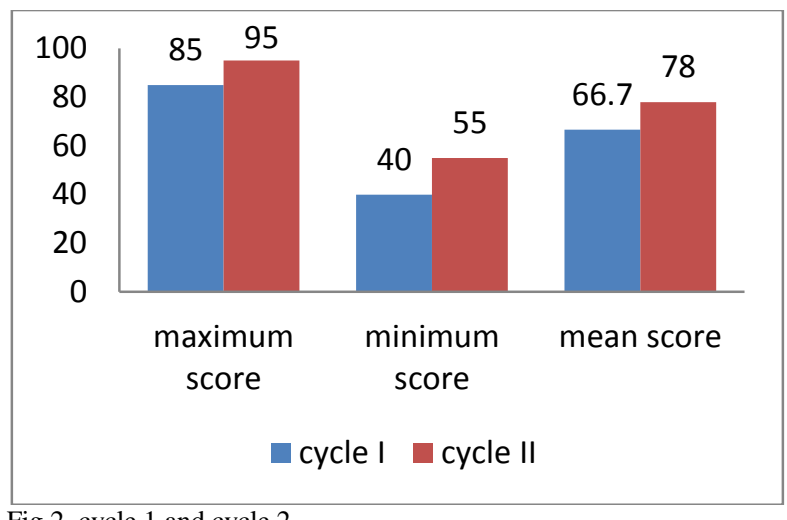

Fig.2. cycle 1 and cycle 2

Based on the results of cycle I and cycle II can be said that there is an increase in the results of learning mathematics students of class XI IPA1 MA DDI Tellu Limpoe in the even semester after use of project-based learning with visual media. The result of observation on the student activity is obtained by observing the change of student attitude in the learning process in Cycle II when project-based learning along with visual media is applied.

The type of student activity to be observed in cycle II is the same as the type of activity in cycle I which is all student activity in learning mathematics by using project-based learning along with visual media. Overall the average development of student activity from cycle I to cycle II has increased.

If the percentage of students in cycle I and cycle II is included in diagram 4.3, it will appear as follows. 


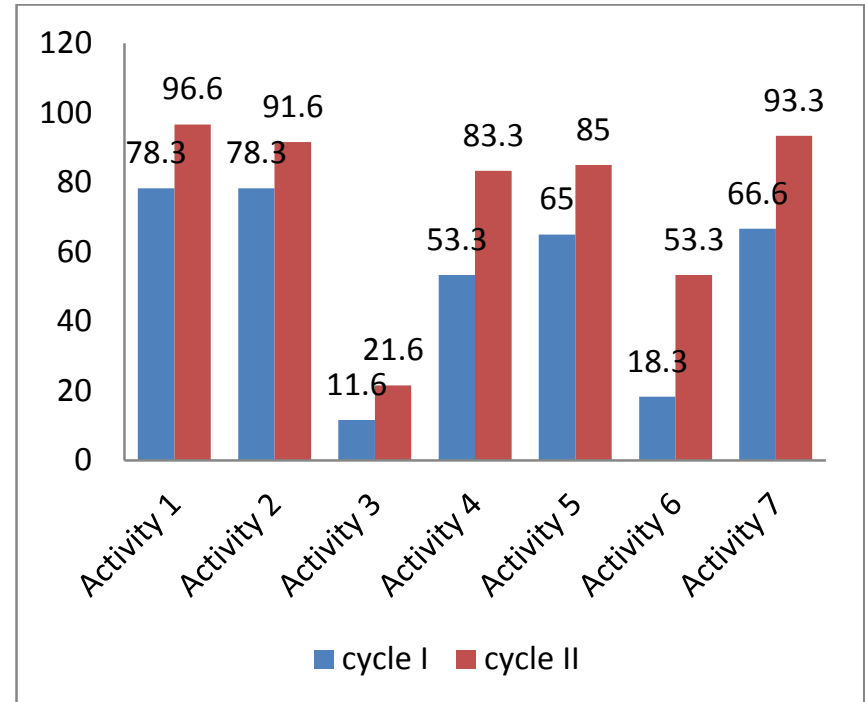

Fig.3. cycle 1 and 2

The result of observation in cycle II shows that the learning activity has progressed better than cycle I. Activity and student participation in cycle II is considered enough that students start to give opinions, motivated in doing task, willing to give responses to opinions of others and students can understand the material given, that is able to relate problems faced with previous things so as to be able to answer questions in accordance with the related material.

\section{B. Discussion}

Based on the result of the research, it can be seen that the data collected has fulfilled and in accordance with the indicators and the format of the observation guide. In the implementation of project-based learning along with visual media students are expected to be active in learning mathematics, by developing the ability and creativity as well as the full responsibility that existed in the students so that the math learning goes as expected.

This research was conducted with the aim of improving students' mathematics learning outcomes, as a whole after two cycles of research proved that project-based learning along with visual media applied in the learning process can improve student learning outcomes. This can be seen from the increase of student learning achievement from cycle I to cycle II, and the increasing of student activity in learning process from cycle I to cycle II.

From the beginning of the study until the end of this cycle recorded an increase that occurs in students, namely:

1) Increase students' mastery score of $75 \%$ in cycle I to $90 \%$ complete classically in cycle II.

2) Increased activity conducted by the students in accordance with that contained in the observation sheet increased from cycle I to cycle II.

\section{CONCLUSION AND SUGGESTION}

\section{A. Conclusion}

Based on the results of research and discussion that has been described in the previous chapter, it can be concluded that the application of project-based learning model along with visual media improve the learning outcomes of mathematics and student activity class XI IPA1 MA DDI Tellu Limpoe. This is indicated by: [1]

1. Increasing the average score of students' mathematics learning outcomes from cycle I to cycle II, that is 66.70 to 78.00 (increased 11.3\%).

2. Increasing the percentage of students' learning mastery from cycle I to cycle II, that is $75 \%$ to $90 \%$ (increased $15 \%$ ) thoroughly classical in cycle II

3. Increased student activity in the learning process from cycle I to cycle II. In the implementation of learning, students are more active both inside and outside the classroom. In addition, students also better understand the material provided and can perform individual tasks as well as group assignments provided

\section{B. Suggestion}

Based on the results of research, discussion and conclusions obtained in this study, then put forward the following suggestions:

1. It is expected that teachers should pay more attention to the models, methods and approaches used in the learning process and can create better and better learning, especially in mathematics learning.

2. Expected to the students to further enhance their creativity and high responsibility in the learning process. In addition, dare to express opinions and questions when there is difficulty in learning mathematics.

3. It is expected that the school to maximize the facilities and infrastructure, such as print books, stationery and learning media that will be used in the learning process.

\section{REFERENCES}

[1] Muhammad Rajabi, Pengembangan Perangkat Pembelajaran Instalas Sistem Operasi Dengan model Pembelajaran Berbasis Proyek, Surabaya: Unesa, 2014.

[2] S. Wina, . Strategi Pembelajaran Berorientasi Standart Proses Pendidikan, Jakarta : Kencana Prenada Media., 2006.

[3] Angkowo Robertus dan A. Kosasih 2007, Optimasilasi Media Pembelajaran, Jakarta: Diva press, 2007.

[4] Buhaedrah, Pengmbangan Perangkat Pembelajaran Berdasarkan Masalah pada Materi Statistik Di kelas IX SMP Makasar, Makasar, 2009.

[5] Asmani, Jaman ma'mur 2011., 7 Tips aplikasi Pakem, Jogjakarta : Diva Press, 2011.

[6] Daryanto, Panduan Proses Pembelajaran Kreatif dan Inovatif, Jakarta: AV Publisher, 2009.

[7] O. Hamalik, Perencanaan pembelajaran berdasarkan pendekatan sistem, Bandung: Bumi Aksara, 2001.

[8] Komariah, "Macam Macam Metode Pemelajaran," [Online]. Available: http://www.Semeru,or.id/../3553.pdf. [Diakses 11 Maret 2011]. 
[9] M. Muchlis, KTSP Pembelajaran berbasis kompetensi dan Konstekrual, Muchlis: Bumi Aksara, 2009.

[10] S. Robet, Cooperative Lierning, Bandung: Nusa Media, 2010.

[11] Soedjadi, Kiat Pendidikan Matematika di Indonesia, Jakarta: Direktorat Jendral Pendidikan Tinggi Depatermen Pendidikan Nasional, 2000.

[12] S. Erman, Strategi Pembelajaran Matematika, Bandung: JICA Universitas Pendidikan Indonesia (UPI), 2001.

[13] S. Erman, 2003, Jakarta: FPMIPA UPI, Model Belajar Mengajar Kontemporer.

[14] Warsita, Teknologi Pembelajaran, Jakarta: Rineka Cipta, 2008.

[15] W. Made, Strategi Pembelajaran Inovatif Kontemporer, Jakarta: Bumi Aksara, 2009.

[16] Komahirah, "Meningkatkan Minat Siswa Terhadap Matematika Melalui Metode Proyek," [Online]. Available:

http://eprints.umm.ac.id/9950. [Diakses 11 maret 2011]. 